\title{
Additional information on reproductive behavior of the Red-breasted Toucan, Ramphastos dicolorus (Aves: Piciformes: Ramphastidae)
}

\author{
Daniel Fernandes Perrella ${ }^{1, *}$ (을 \& Fernanda Junqueira Vaz Guida ${ }^{2}$ \\ ${ }^{1}$ Universidade Federal de São Carlos, Programa de Pós-Graduação em Ecologia e Recursos Naturais, \\ São Carlos, SP, Brasil \\ ${ }^{2}$ Fundação Parque Zoológico de São Paulo, São Paulo, SP, Brasil
}

${ }^{*}$ Corresponding author: Daniel F. Perrella,e-mail: dfperrella@gmail.com

PERRELLA, D. F., GUIDA, F. J. V. Additional information on reproductive behavior of the Red-breasted Toucan, Ramphastos dicolorus (Aves: Piciformes: Ramphastidae). Biota Neotropica. 19(1): e20180576. http://dx.doi.org/10.1590/1676-0611-BN-2018-0576.

\begin{abstract}
Ramphastidae is Family of secondary cavity-nesting birds that is endemic to the Neotropical region. Here we provide a comprehensive literature review of nest measurements, and new information on characteristics of the nest cavity, parental nest attendance, incubation and nestling period of the Red-breasted Toucan, Ramphastos dicolorus. We also add information on the origin of the seeds found inside toucan nests and propose a potential function for them. Eight nests were studied in three cavities during six breeding seasons at Parque Estadual das Fontes do Ipiranga, São Paulo, and at a private allotment in Ibiúna, southeastern Brazil. The reproductive activities of the birds were observed from September to February. In one cavity, we found the first record of a Meliponini bee hive (Scaptotrigona bipunctata) co-existing with a toucan nest. At the beginning of the nesting season, the parents regurgitate seeds on the floor of the cavity, covering it with them. This preparation plays a role in nest sanitation, once the seeds act as a substrate for the feces facilitating the process of carrying them off the nest by the female. The incubation and nestling periods lasted $17.2 \pm 1.2$ and $43 \pm 5.4$ days, respectively, and both parents shared egg incubation, nestling, brooding and provisioning, but only the female performed nest sanitation. This differs from published observations on other species of the group, suggesting that the participation of each sex in nest attendance may not be the same for all ramphastids. Additionally, our observations suggest that selecting anthropic locations for nesting can negatively influence toucan nest success.

Keywords: Breeding biology, cavity-nester, hive coexistence, incubation and nestling periods, regurgitated seeds.

\section{Informações adicionais sobre o comportamento reprodutivo do tucano-de-bico-verde, Ramphastos dicolorus (Aves: Piciformes: Ramphastidae)}

\footnotetext{
Resumo: Ramphastidae compreende uma Família de aves que nidificam em cavidades, são endêmicas da região Neotropical, mas possuem os aspectos relacionados à sua biologia reprodutiva ainda pouco conhecidos. No presente estudo, nós fornecemos uma revisão detalhada da literatura acerca de medidas de ninhos, características das cavidades, cuidado parental e períodos de incubação e permanência do tucano-de-bico-verde Ramphastos dicolorus. Nós também descrevemos e propomos uma possível função para as sementes encontradas dentro dos ninhos dessa espécie. Foram estudados oito ninhos, em três diferentes cavidades durante seis temporadas reprodutivas no Parque Estadual das Fontes do Ipiranga, São Paulo, e em um loteamento particular em Ibiúna, ambos no sudeste do Brasil. As atividades reprodutivas foram observadas de Setembro a Fevereiro. Em uma das cavidades foi registrada a coexistência entre uma colmeia de abelhas Meliponini Scaptotrigona bipunctata e um ninho de tucanos, sendo este o primeiro registro desse tipo de interação para Ramphastidae. No início do período de nidificação os parentais regurgitavam sementes no fundo da cavidade, cobrindo-o, e nossas observações mostram que essa preparação desempenha o papel de facilitar na limpeza do ninho, uma vez que as sementes servem como substrato para as fezes e possibilitam que a fêmea possa carrega-las para fora. Os períodos de incubação e permanência dos filhotes no ninho duraram 17,2 $\pm 1,2$ e $43 \pm 5,4$ dias, respectivamente, e ambos os parentais dividiram a incubação dos ovos, aquecimento e alimentação dos ninhegos, mas somente a fêmea realizou a limpeza do ninho. Entretanto, tais comportamentos observados para o tucano-de-bico-verde são diferentes do que se conhece para outras espécies do grupo, sugerindo que o investimento de cada membro do casal no atendimento ao ninho pode não ser o mesmo para todos os ramphastídeos. As observações realizadas também mostram que a seleção de locais antropizados para nidificar poderia influenciar negativamente o sucesso reprodutivo dos tucanos.

Palavras-chave: Biologia reprodutiva, coexistência com uma colmeia, nidificação em cavidade, períodos de incubação e permanência, sementes regurgitadas.
} 
Perrella, D.F. et al.

\section{Introduction}

Ramphastidae, including toucanets and toucans, is a family of thirty-four medium to large birds that are endemic to the Neotropical region (Short \& Horne 2002, Remsen et al. 2017). These birds are remarkable for their colorful plumage and very large bills, which play several ecological and behavioral functions (Sick 1997, Tattersall et al. 2009). Ramphastid diversity is greatest in forested environments, from the lowlands of the subtropical Atlantic Forest to the montane forests of the Andes (Short \& Horne 2002). Toucans are primarily frugivorous and consume many fruits of a wide range of plants, playing an important role in seed dispersal (Galetti et al. 2000, Pizo et al. 2008). Furthermore, their substantial participation in the predation of eggs and nestlings of other birds has been reported (Santos \& Ragusa-Netto 2013, Cockle et al. 2016), highlighting their ecological role as nest predators, while they can also be the prey of larger carnivorous birds (Rangel-Salazar \& Enriquez-Rocha 1993, Arévalo \& Araya-Salas 2013).

Toucans are obligatory cavity nesters. This means that to be able to nest they need to find vacant cavities or usurp occupied ones (Sick 1997, Short \& Horne 2002). Nests are selected mostly from tree cavities made by woodpeckers, or produced by wood decay (Van Tyne 1929, Skutch 1958). Although the basic aspects of toucan nests are well documented, more detailed information on the breeding biology of particular species is scarce. The largest species and subspecies of ramphastids are found in the genus Ramphastos. Generally, the following is known about the nesting habits of species in this genus: the nests of seven species have been described; the eggs and nestling characteristics of six species have been reported; and incubation or nestling periods have been described for five species (Short \& Horne 2001, 2002 and therein references, Filadelfo 2008, Jesus et al. 2012). In the case of the Red-breasted Toucan Ramphastos dicolorus Linnaeus, 1766, only two nest cavities have been measured, with nestling characteristics provided in one contribution (Lange 1967, Jesus et al. 2012). Information on eggs is provided for at least three clutches, one provided by Lange (1967) and two deposited in the Ornithological Collection of the Museu de Zoologia da Universidade de São Paulo - MZUSP from 1905 and 1907. The incubation period is only known for individuals in captivity (Brehm 1969) and parental participation in nestling provisioning has been quantified, without discriminating between female and male contributions (Jesus et al. 2012).

The Red-breasted Toucan is a large bird (42 to $48 \mathrm{~cm}$ ), with black back and tail, red breast and uppertail coverts, and a yellow throat with a central orange area. The bill is mainly green, with a black basal line and some red above the tomial tooth (Short \& Horne 2002). This toucan is found mainly in the Atlantic Forest, from the states of Espírito Santo, Minas Gerais and Goiás to Rio Grande do Sul - Brazil, extending to eastern Paraguay and northeastern Argentina (Sick 1997). Here, we provide new information on the reproduction of the Red-breasted Toucan associated with a literature review. The specific objectives are to 1) present information on the breeding phenology, parental nest attendance, incubation and nestling periods; 2) provide averaged measurements of the cavities used for nesting considering data from the field and literature; and 3) describe the seeds regurgitated by toucans in the nest chamber and hypothesize their potential function.

\section{Materials and Methods}

\section{Study area}

Observations were conducted at Parque Estadual das Fontes do Ipiranga in the city of São Paulo (PEFI, 23 39' 05' S and 46 37' 24" $\mathrm{W}, 526.38 \mathrm{ha}, 810 \mathrm{~m}$ a.s.1.) and at a private allotment in the city of Ibiúna (23 $38^{\prime} 47^{\prime}$ ' S and $47^{\circ} 19^{\prime} 17^{\prime}$ ' W, 151 ha, $860 \mathrm{~m}$ a.s.1.), both in the state of São Paulo, southeastern Brazil.

The allotment in Ibiúna has private houses with extensive lawns, gardens and exotic trees, but also some remnants of native vegetation in the surroundings, which are classified as Lower Montane Rain Forest (Oliveira-Filho \& Fontes 2000). The climate is temperate without a dry season and with hot summers, classified as Cfa according to KoppenGeiger (Peel et al. 2007). The annual rainfall varies from 40 to 214.9 $\mathrm{mm}$ and the temperature averages from 15.3 to $22.3^{\circ} \mathrm{C}$ (Cepagri 2017).

In PEFI the climate is temperate with dry winters and hot summers (Cwa according to Koppen-Geiger classification, Peel et al. 2007). Rainfall ranges from 34.1 to $238.2 \mathrm{~mm}$ and the average temperature varies from 17 to $24^{\circ} \mathrm{C}$ (Cepagri 2017). This Park consists of a preserved fragment of Lower Montane Rainforest, is isolated from other remnants of native vegetation and is surrounded by the urban area of São Paulo (Oliveira-Filho \& Fontes 2000, Fernandes et al. 2002).

\section{Field procedures}

Data were collected for six years, from September to February of 2012/2013, 2013/2014, 2014/2015, 2015/2016, 2016/2017 and 2017/2018. At PEFI one nest was monitored in 2012, and at Ibiúna seven nests were monitored from 2013 to 2017. The nest at PEFI was found while we were walking along a road and observed a toucan getting out of a cavity. The locations of the other nests were reported by local workers. After they were located, the nests were checked once every week. When important events such as egg laying, hatching and fledging were near, we monitored the nests every day after 10:00 a.m. to ensure higher precision in the determination of incubation and nestling periods.

The incubation period was delimited from the first day of incubation to the day before hatching, and the nestling period from the day of hatching to the day before fledging (Winkler 2004). Each period of egg or nestling was considered separately, and when hatching or fledging was asynchronous, it was assumed that the laying order predicted the order of hatching or fledging. Nestlings were never touched to avoid interfering with the duration of nestling period (Skutch 1945). When eggs or nestlings disappeared before the estimated time for hatching or fledging, we assumed that they had been predated (Francisco 2006).

To evaluate participation of the parents in nest attendance during incubation and nestling stages, one-hour sessions of observation were conducted using 8 X $42 \mathrm{~mm}$ binoculars behind a blind (Van Tyne 1929, Skutch 1971), or video between 6:00 and 10:00 a.m. Observations were held in three breeding events of the same cavity in Ibiúna, in which one parent was identifiable due to a large and evident scar on the bill. We considered the scar-billed toucan as the female because its bill was shorter, and this represents a sexual dimorphism feature for $R$. dicolorus (Castro et al. 2003).

All nests were located inside tree cavities and were measured after the breeding period. The cavities were measured with a metal caliper of $0.1 \mathrm{~mm}$ precision (horizontal and vertical lengths of the chamber entrance) or a measuring tape (for other dimensions). The following measurements were made: height of the cavity (from the lower lip of 
the entrance to the ground), diameter of the tree at breast height, vertical and horizontal diameters of the entrance (taken in the larger diameter of each one), depth of the cavity (from the lower lip of the entrance to the cavity bottom), and the diameter of the cavity, measured from the lower internal lip of the entrance to the back wall of the cavity (Lange 1967). It was not possible to take the eggs out to measure, but they were classified according to their shapes, as proposed by Winkler (2004). To describe the material deposited inside the nest cavity, the contents of the bottom of one nest (from PEFI) were collected after the fledgling left the nest. The content was washed only with water, and then dried and identified.

\section{Statistical analyses}

Parental investment during incubation, nestling provisioning and nest sanitation were averaged, and ranges were given for the number or duration of events per hour of observation. Differences in the participation of male and female for each activity were analyzed using the Student T-test in software R 2.15.3 (R Development Core Team, 2013). The average and the standard deviations of the measurements of cavities were calculated considering also the nests observed by Lange (1967) and Jesus et al. (2012), and were presented as means \pm SD. The amount of seeds found in the content of cavity was presented as percentages for each species in relation to the total amount of seeds.

\section{Results}

Eight nesting attempts of Red-breasted Toucans were recorded in three cavities during six breeding seasons; all in anthropic habitats near forest remains (Table 1). The reproductive activity, considering all seasons, occurred from early October to early February (Figure 1). The earliest reproductive activity was observed on 02 September 2015 during nest preparation for laying, and the latest nestlings were observed on early February 2017.

\section{Nest site and seeds used inside cavity}

The nest sites selected were cavities produced by wood decay ( $n=1$ nest) or excavated by woodpeckers $(n=2)$. One of the trees excavated by woodpeckers (unidentified species, Figure 2 ) and the tree with wood decay cavity (Persea americana Mill.) were alive and apparently healthy. The third tree (excavated by woodpecker) was a dead trunk of an unidentified palm. The trees were near the edges of a lake

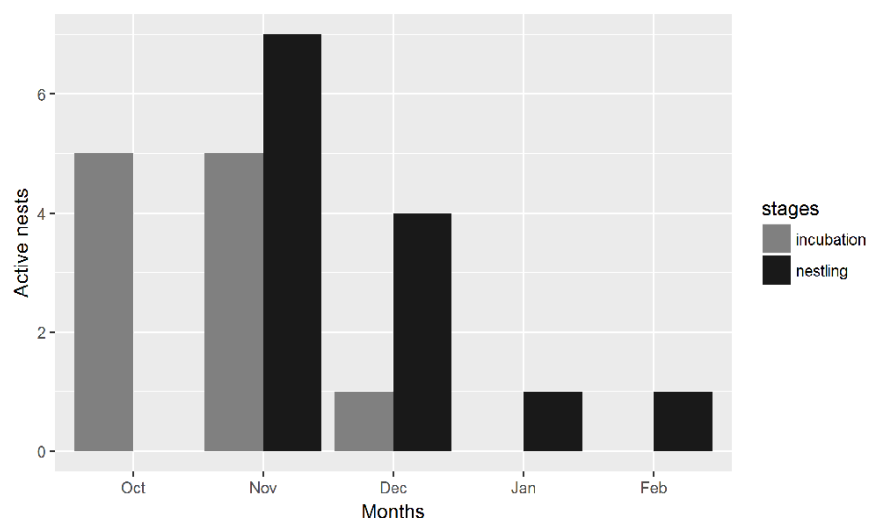

Figure 1. Cumulative number of active nests during incubation and nestling stages from 2012/2013 to 2017/2018 breeding seasons.

$(\mathrm{n}=1)$ or a dam $(\mathrm{n}=2)$, and the diameter of the trunks were $81.3 \mathrm{~cm}$ \pm 46.7 (range $=42-133 \mathrm{~cm} ; \mathrm{n}=3$ cavities). In the tree found in PEFI, produced by wood decay, there was an active hive of Meliponini bees Scaptotrigona bipunctata (Holmberg), apparently positioned directly under the floor of the toucan nest. The entrance of the hive was located directly below the entrance of the toucan nest, but no bee attacks on toucans were observed.

The floors of all cavities were covered with several seeds, from at least 10 species of plants. The most highlighted seed in the entire content was from the exotic Archontophoenix sp and the most abundant was from the native Cecropia glaziovii Snethl. (Table 2). The nest contents also included heads and legs of Coleoptera insects Macraspis $\mathrm{sp}(\mathrm{n}=4$ individuals) and old bones of a young toucan, probably from previous nesting events.

During four breeding seasons we were able to record the adults preparing the nests for egg-laying in the same tree cavity at Ibiúna. During a 3-hour observation at this stage, male and female visited the cavity 1 - 4 times/ $\mathrm{h}$ and remained inside the nest for an average of $9 \mathrm{~min} /$ $\mathrm{h} \pm 6 \mathrm{~min}$ (range $=2$ - 16 min per visit), sometimes together. Although we were not directly observing toucans bringing and depositing the seeds (because they regurgitate it), the daily monitoring showed evident changes inside the nests: 1) before the toucans began to use the cavity, the floor was dirty, with dark material, and sometimes it was possible to see sprouted seedlings (Figure 3 a). 2) When toucans started visiting,

Table 1 - Cavities measurements considering nests monitored in the present study and reported in literature.

\begin{tabular}{|c|c|c|c|c|c|c|c|}
\hline \multirow[b]{2}{*}{ Nest } & \multirow[b]{2}{*}{ Tree condition } & \multicolumn{6}{|c|}{ Cavity measurements (cm) } \\
\hline & & Cavity height & Tree Diameter & $\begin{array}{c}\text { Entrance } \\
\text { horizontal } \\
\text { diameter }\end{array}$ & $\begin{array}{c}\text { Entrance } \\
\text { vertical } \\
\text { diameter }\end{array}$ & Cavity depth & Cavity diameter \\
\hline Lange 1967 & - & 600 & - & 8.5 & 6.5 & 15 & 13 \\
\hline \multirow[t]{2}{*}{ Jesus et al. 2012} & Alive & 90 & - & 4.0 & 9.0 & 62 & 15 \\
\hline & & 70 & & 3.5 & 11 & & \\
\hline Ibiúna 1 & Alive & 121 & 133 & 7.5 & 7.0 & 56 & 12 \\
\hline Ibiúna 2 & Dead & 580 & 69 & 9.0 & 10.5 & 40 & 7.5 \\
\hline Total average & - & 290 & 81.3 & 6.4 & 8.8 & 64.8 & 11.9 \\
\hline
\end{tabular}


Perrella, D.F. et al.

Table 2 - Seeds found in one nest of Ramphastos dicolorus.

\begin{tabular}{lllc}
\hline \multicolumn{1}{c}{ Taxa } & \multicolumn{1}{c}{ Scientific name } & Status & Units \\
\hline Arecaceae & Archontophoenix sp & Exotic & $542(18 \%)$ \\
& Euterpe edulis Mart. & Native & $08(0.3 \%)$ \\
Caricaceae & Carica papaya L. & Exotic & $369(12 \%)$ \\
Cecropiaceae & Cecropia glaziovii Snethl. & Native & $1900(62 \%)$ \\
Lauraceae & Ocotea odorifera (Vell.) Rohwer & Native & $70(2.3 \%)$ \\
Myrsinaceae & Rapanea sp & Native & $11(0.4 \%)$ \\
Myrtaceae & Myrcia tomentosa (Aubl.) DC. & Native & $92(3 \%)$ \\
Verbenaceae & Cytharexyllum myrianthum & Native & $36(1 \%)$ \\
- & Cham. & & $09(0.3 \%)$ \\
- & Not identified & - & $22(0.7 \%)$ \\
\hline
\end{tabular}

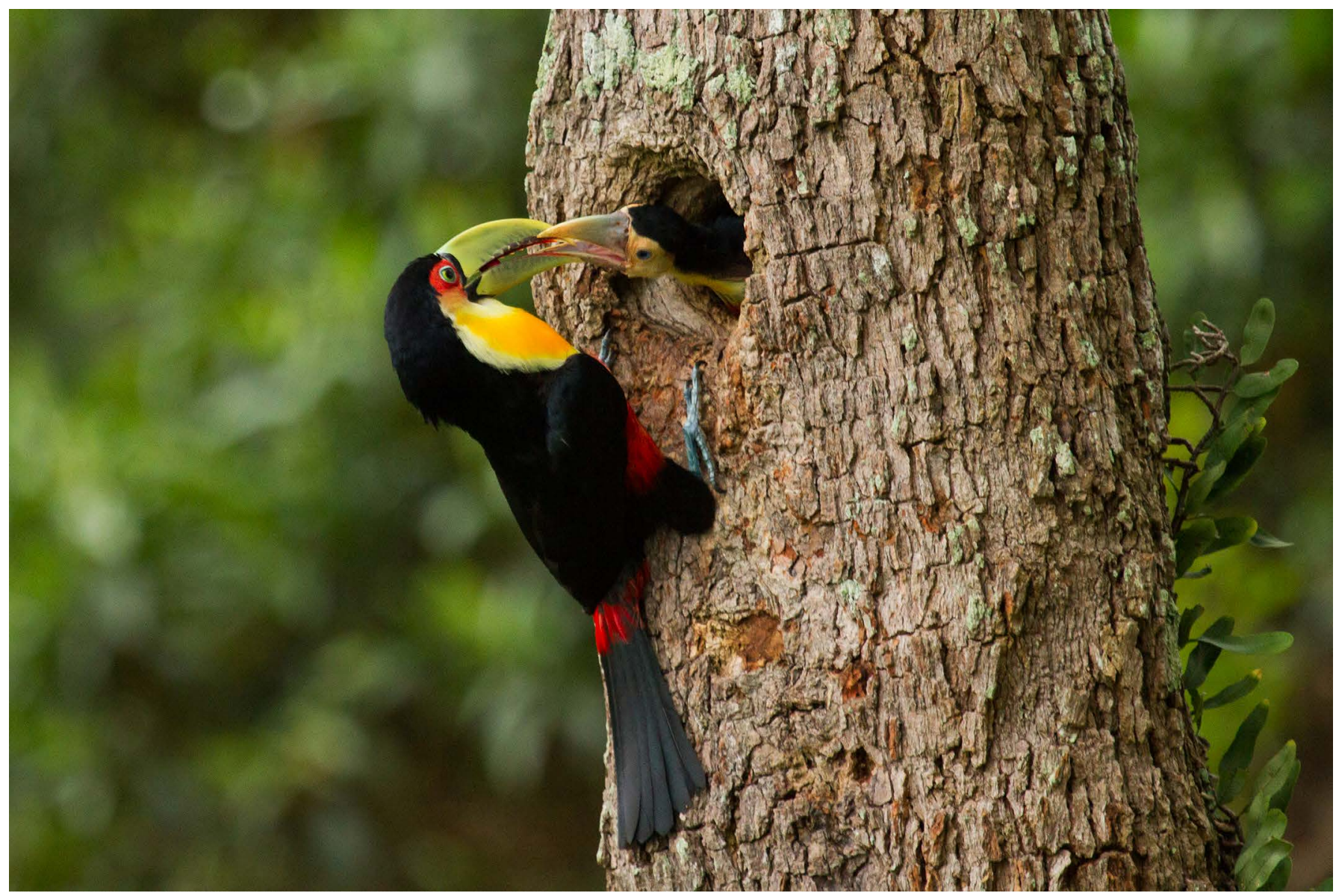

Figure 2. Woodpecker excavated cavity used by Ramphastos dicolorus and an adult provisioning late staged nestling.

some seeds were observed inside the nests and their number increased daily until the floor was completely covered (Figures $3 \mathrm{~b}$ and $\mathrm{c}$ ). We believe that these seeds were regurgitated because they were scarified and totally clean. 3) Thus, toucans were laying the eggs on a "bed" of seeds (Figure 3d). 4) Later, when the nestlings hatched they messed up the "bed" while developing (Figure 3e). 5) After fledging, the cavity floor was dirty again, and remained so until the next nesting activity (Figure 3f).
The walls of the cavities were scratched, and some pieces of wood were observed in one nest during seed deposition (Figure 3b), suggesting that toucans lightly tear the walls of cavities before laying. The height of the cavities ranged from 1.21 to $5.8 \mathrm{~m}(3.3 \mathrm{~m} \pm 2.3 ; \mathrm{n}=3)$ above the ground, cavity depth averaged $82.3 \mathrm{~cm} \pm 60($ range $=40-151 \mathrm{~cm}$, $\mathrm{n}=3)$, inside diameter $10.5 \mathrm{~cm} \pm 2.6($ range $=7.5-12 \mathrm{~cm} ; \mathrm{n}=3)$, and cavity entrance averaged $7.5 \mathrm{~cm} \pm 1.5$ (horizontal length, range $=$ $6-9 \mathrm{~cm} ; \mathrm{n}=3$ ) per $8.8 \pm 1.7$ (vertical length, range $=7-10.5 ; \mathrm{n}=3$ ). 

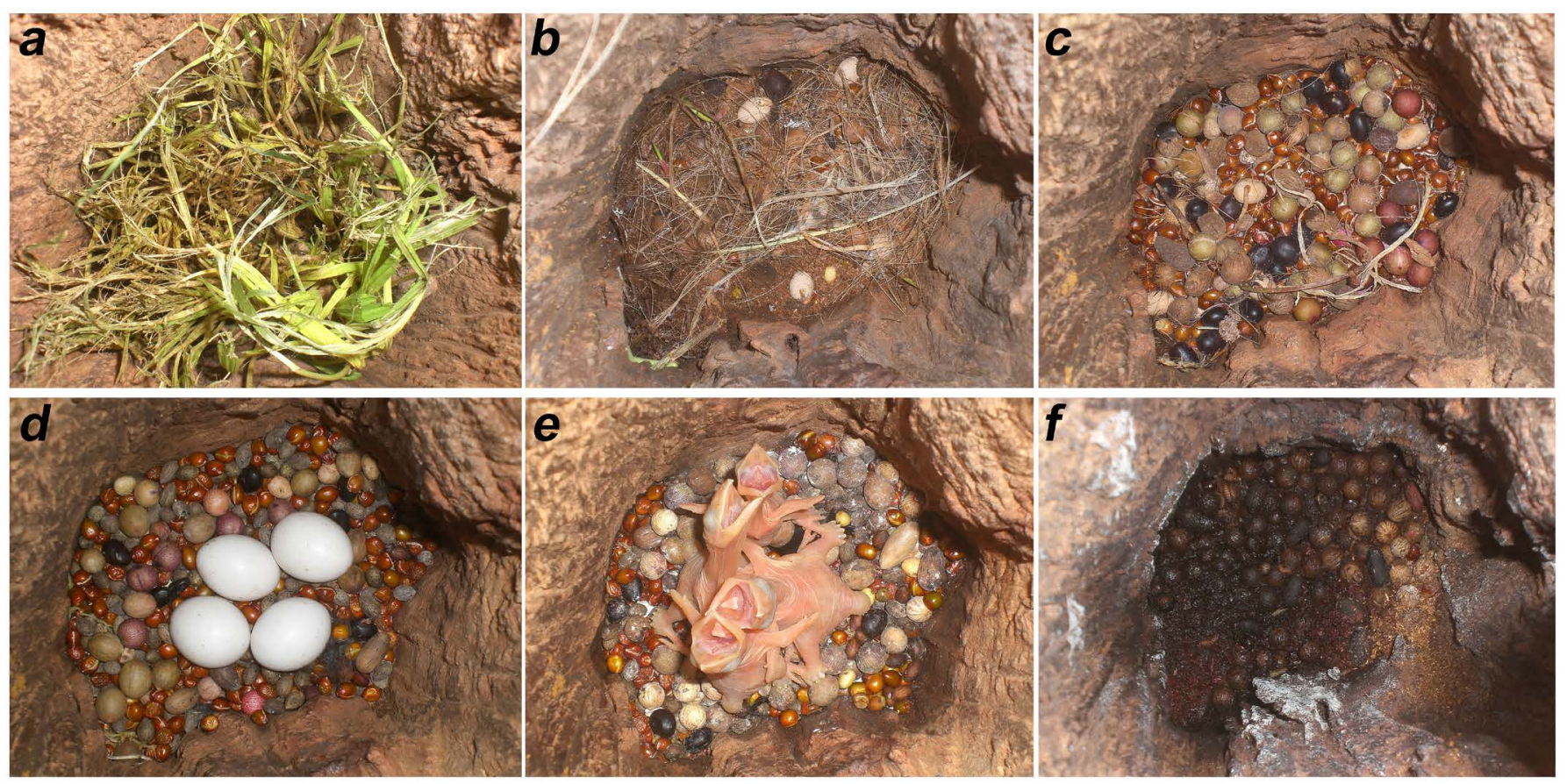

Figure 3. Seeds on the floor during different nesting stages: a - cavity floor dirty with sprouted seedlings; $b$ - initiation of nest cleaning and seed depositing; $c$ - nest floor with many seeds before laying; $\mathrm{d}$ - Eggs on the "bed" of seeds; $\mathrm{e}$ - Three days old nestling and seeds becoming dirty; $\mathrm{f}$ - seeds dirty in the nest after fledging.

The average of cavities' measurements, including the two nests reported in the literature, are presented in Table 1.

\section{Eggs, nestlings, and periods}

Clutch size varied between three ( $n=2$ nests) or four eggs $(n=5$ nests). Eggs were white, and short oval (Figure 3d), but became dirty during incubation. In three of the eight breeding events monitored, the incubation period was recorded with precision. In two nests, eggs were laid on consecutive days, and in one nest with tree eggs, the first two were laid on consecutive days, but the third was laid two days later. The incubation began in the morning that the females laid the first eggs in three nests. The incubation periods were 16 (4 eggs), 17 (2 eggs), 18 ( 2 eggs), or 19 days ( 2 eggs) averaging $17.2 \pm 1.2$ days (10 eggs from three nests).

Hatching was synchronous in one nest (with three eggs, only two of which hatched) and asynchronous in other two nests (with four eggs, three of which hatched in the same day and one hatched one day later). The nestling periods of six young from two nests were $39(\mathrm{n}=2), 40(\mathrm{n}=$ $2)$, and 50 days $(n=2)$, averaging $43 \pm 5.4$ days. Hatchings were devoid of a down, were blind, had pinkish skin and displayed pronounced heel pads ( $n=4$ nests). Their bills and the interior of their mouths were short and pinkish (Figure 3e). They did not have swallow flanges but the tip and borders of their maxillae and mandible were bright white. In two nests we were able to observe the entire development of nestlings, on the second week the nestlings were considerably larger, and their tracts were greyish and visible. On the third week, their eyes were open, sheaths were present, and their bills became greenish. On the fourth week the sheaths were open, and their bills were apparently solid and green. On the fifth week the nestlings were well feathered, and on the sixth week they would put their heads out of the entrance of the cavity to wait for food from the parents (Figure 2). Fledgling are very similar to adults in plumage, but their bills are considerably shorter and paler.

\section{Nest attendance}

In over 16 hours of observations of three nests during the incubation stage, eggs were attended by both parents on average $94 \%$ of the time. The female incubated the eggs for $445 \mathrm{~min}$ while the male spent 454 min in this activity, resulting in no difference in the average time spent for incubation between sexes (female $27.5 \pm 22.4 \mathrm{~min} / \mathrm{h}$, male $28.2 \pm$ $20.5 \mathrm{~min} / \mathrm{h}, \mathrm{t}=-0.07, \mathrm{P}=0.94)$. During incubation, parents put their heads out of the cavity to keep a watch, for about 1,2 or 4 times per hour during $0.1-17$ minutes for female $(2.1 \pm 4.5 \mathrm{~min} / \mathrm{h})$ and $0.15-$ 6.8 minutes for male $(1.5 \pm 2.5 \mathrm{~min} / \mathrm{h})$.

In 20 hours of observation at three nests during the nestling stage (all nests with four nestling each one), the young were provisioned 1 - 6 times per hour by both parents (female $2.6 \pm 1.1$ times/ h, male $1.8 \pm$ 1.2 times $/ \mathrm{h}$ ), but the proportion of visits by the female was significantly higher $(\mathrm{t}=2.2, \mathrm{P}=0.03)$. During these observations, parents were recorded brooding young six times (female $32.5 \pm 10.5 \mathrm{~min} / \mathrm{h}$, and male $19.2 \pm 9.2 \mathrm{~min} / \mathrm{h}$ ), only in the early nestling stage. Nest sanitation was performed only by the female, who carried away dirty seeds with feces in her bill 0 - 4 times per hour ( 1.5 times $/ \mathrm{h} \pm 1.4$ ). Nestlings were provisioned mainly with entire fruits carried by parents in their bills. During the visits where the content of the bill could be identified, $98 \%$ were fruits and $2 \%$ were bird eggs. A bird leg was observed being carried out once. When nestlings became larger, the parents began to deliver food from outside of the cavity's entrance, and episodes were recorded in which toucans also carried fruits in their gizzards to regurgitate and to offer to the nestlings (Figure 2).

\section{Nest loss and predation}

From the eight breeding events that were monitored, two nests were predated, one was abandoned and five were successful. Predation occurred during incubation $(12.5 \%)$ and the nestling stage $(12.5 \%)$. 
Perrella, D.F. et al.

One nest was lost due to human disturbance during the nestling stage $(12.5 \%)$, and five others were successful raising their young to the fledging stage $(62.5 \%)$. On one instance we saw a Southern Caracara Caracara plancus (Miller, 1777) predating upon one fledgling that was caught while perching on an exposed scrub on the lawn around the nest tree. We also saw the fledglings of another nest being attacked by a Black-and-white Teju Salvator merianae (Duméril \& Bibron, 1839) when they went down to the ground. During the attacks, the parents remained on the trees above for a long time, restless and vocalizing frequently.

Abandonment due to human disturbance occurred after the pruning of a tree near the nest. The parents ceased provisioning the nestlings probably as a result of the loud sounds and intense movement around it. The hungry young left the nests earlier and flightless. Although the young were returned to the nest by our team, they disappeared the next day.

\section{Cavity reuse}

The cavity in PEFI and one of the cavities in Ibiúna were monitored only during one breeding season, but the third one could be monitored for longer and was used by toucans in all seasons from 2012 to 2017. Although the toucans were not marked, we believe that at least one member of the couple used the cavity for reproduction in all events. We could recognize it based on a scar on its bill. In 2016, the young from this cavity's nest were predated upon during the nestling stage around 15 November, and was reused in early December, resulting in four fledging in early February 2017. This same cavity was also reused in September 2017.

\section{Discussion}

The height of the cavities used by Red-breasted Toucan measured by Jesus et al. (2012) and Lange (1967) had discrepant values, ranging from 70 to $600 \mathrm{~cm}$ above ground, respectively. In the present study, the nests were 121 and $580 \mathrm{~cm}$ above ground. Only one nest in our observations was recorded on a dead tree. It has been documented that nest success can be higher in living trees than in dead ones, because the walls of the holes of living trees are stronger and thicker (Wesołowski 2002, Cockle et al. 2015). Height above ground, in contrast, does not seem to be significant in nest survival for large cavity-nesting birds as toucans (Cockle et al. 2015). Small nest entrances also seem to be an important feature in the cavities used by the Red-breasted Toucan, but although species of smaller birds have higher nest survival rates when selecting cavities with smaller entrances (Wesołowski \& Rowiński 2004, 2012, Zhu et al. 2012), large birds apparently do not (Cockle et al. 2015). Small entrances might help to avoid large nest predators as coatis and birds of prey (Van Tyne 1929, López-Lanús 2000, Pizo et al. 2008).

Although nests in cavities have been considered more efficient to ensure offspring survival (Auer et al. 2007), many species of predators are able to access the contents of these nests (Berkunsky et al. 2011, Cockle et al. 2016). The construction of nests in association with insect colonies has been reported as a protection strategy used by several species of birds (see Hansell 2000 for review), since ants, wasps and bees can be aggressive and attack other animals that are approaching their nests (Myers 1935, Moreau 1942). To our knowledge, this is the first record of a toucan nesting in association with a social insect, and we believe that this interaction was beneficial for $R$. dicolorus because no attack to the toucans was observed during field work, while the bees always tried to attack people who got close to the nest for inspection. Meliponini bees are stingless, but their aggressive behavior against intruders is common in some species (Knoll et al. 1993). The absence of attacks against the toucans was probably related to the disjunction between the toucan cavity and the hive cavity, besides the fact that the birds tend to enter and exit the nest very rapidly.

Nest attendance between the sexes has been recorded for several species of Ramphastids as Aulacorhynchus prasinus (Gould, 1833), A. caeruleogularis Gould, 1854, Ramphastos sulphuratus Lesson, 1830, R. vitellinus Lichtenstein, 1823 and even $R$. dicolorus (Van Tyne 1929, Skutch 1944, Lill 1968, Riley 1986, Jesus et al. 2012), but the proportion of the contribution during incubation, provisioning and nest sanitation by each sex has remained poorly understood. The $R$. dicolorus couple monitored by us shared incubation and nestling provisioning, but only the female was involved in nest sanitation. Females of the Emerald Toucanet, Aulacorhynchus prasinus (Riley 1986), tend to be more engaged in nest attendance, while in the case of the Pale-billed Araçari Pteroglossus erythropygius (Gould, 1843) both sexes seem to be equally involved (Berg 2001). However, for these two species, the male participated in nest sanitation, suggesting that the nest attendance activities may not be the same for all Ramphastidae species or individuals.

Seeds found inside the nest can reflect a portion of the diet of the adults in the study area (Riley 1986, Van Tyne 1929). About $62 \%$ of the seeds that were identified in our study are consumed by $R$. dicolorus (Galetti et al. 2000, Guix et al. 2001, Alvarenga et al. 2004, Fonseca \& Antunes 2007). Nesting in cavities that have seeds inside is common among toucans and toucanets (Van Tyne 1929, Skutch 1958, Lill 1968, Jesus et al. 2012), and the presence of these seeds in nests have been considered accidental (Van Tyne 1929, Lill 1968). However, we believe that the deposition of seeds in cavities is part of the nest preparation process and plays an essential role in nest sanitation. Since toucans do not produce fecal sacs, the seeds act as a substrate for the feces, facilitating the process of carrying them off the nest by the female bird (Filadelfo 2008, Jesus et al. 2012).

Toucans and toucanets are mostly frugivorous and important seeds dispersers in the habitats where they live (Galetti et al. 2000, RagusaNetto 2008). However, consumption of animals such as arthropods, eggs and nestlings has been recorded for many species (Skutch 1958, Riley 1986, Cockle et al. 2016), but in lower rates than fruits (Remsen et al. 1993, Ragusa-Netto 2008). During our observations of nestling attendance, a few instances of animal matter consumption were recorded. Yet, this might be underestimated because the toucans brought unseen food in the craw. Toucans in general seem to be representative predators of eggs and nestlings (see Menezes \& Marini 2017 for review), which would be related to the timing of the toucans' and passerines' breeding season, since young Ramphastids usually eat protein sources during their development even when their diet is mostly frugivorous (Brehm 1969, Remsen et al. 1993).

Red-breasted Toucan nests were observed in environments disturbed by humans, and although toucans can find fruits from exotic tree species for nestling provisioning even in these landscapes (Guix et al. 2001, Fonseca \& Antunes 2007) and to be well succeeded in some reproduction attempts in anthropic habitats (Jesus et al. 2012, this work), 
in two situations the fledglings were exposed to predation by the absence of an understory structure for perching and hiding. Moreover, in a third situation, direct human disturbance resulted in premature fledging. Thus, we believe that the selection of anthropic locations by toucans for nesting negatively influenced nest success in the reported cases.

In conclusion, our contribution provides information about parental attendance, incubation and nestling period in $R$. dicolorus, and our literature review subsumes all available data on nest measurements for this species, providing a better understanding of its breeding biology. Our observations also suggest a different interpretation how these birds use regurgitated seeds on the floor, as nest material deposited purposely for facilitating nest sanitation.

\section{Acknowledgements}

The authors thank ICMBio and Instituto de Botânica for their permissions for field work in PEFI (SISBIO ${ }^{\circ}$ 35526-1, Instituto de Botânica ${ }^{\circ} 16 / 2012$, and nº3/2013); Fundação Parque Zoológico de São Paulo for financial support; Parque de Ciência e Tecnologia da USP and Associação Veleiros de Ibiúna for field support. We are also grateful to Daniel Ferrari, Estanislau Firmino da Silva, Michele Viana for helping in the field; Paula Andrea and Carolina Chagas for laboratory assistance; and Maurílio Ferreira dos Santos, Altevir Mascarello and Claudio Gabriel Vieira for important assistance in monitoring the nests. We also thank Marco A. Crozariol and Thiago Filadelfo for important comments on early versions of this manuscript, Danilo Costa Silva and Marcos Melo for figures editing, and Ingrid Scheeffer, Alice Reisfeld and "Científica Publicações" for English text review.

\section{Author Contributions}

Daniel Fernandes Perrella: Substantial contribution in the concept and design of the study; Contribution to data collection; Contribution to data analysis and interpretation; Contribution to manuscript preparation; Contribution to critical revision, adding intelectual content. Fernanda Junqueira Vaz Guida: Substantial contribution in the concept and design of the study; Contribution to data collection; Contribution to critical revision, adding intelectual content.

\section{Conflicts of interest}

The authors declare that they have no conflict of interest related to the publication of this manuscript.

\section{References}

ALVARENGA, H., BRETTAS, E. \& PONTUAL, M. 2004. Tucanos da Américas M. Pontual Edições e Arte, Rio de Janeiro.

ARÉVALO, J.E. \& ARAYA-SALAS, M. 2013. Collared Forest-Falcon (Micrastur semitorquatus) preying on Chestnut-mandibled Toucan (Ramphastos swainsonii) in Costa Rica. Wilson J. Ornithol. 125(1):212-216.

AUER, S.K., BASSAR, R.D., FONTAINE, J.J. \& MARTIN, T.E. 2007. Breeding biology of passerines in a subtropical montane forest in northwestern Argentina. Condor 109:321-333.

BERG, K.S. 2001.Notes on the natural history of the Pale-mandibled Araçari. J. Field Ornithol. 72(2):258-266.

BERKUNSKY, I., KACOLIRIS, F.P., FAEGRE, S.I.K., RUGGERA, R.A., CARRERA, J. \& ARAMBURÚ, R.M. 2011. Nest predation by arboreal snakes on cavity nesting birds in dry Chaco Woodlands. Ornitol. Neotrop. 22:459-464.
BREHM, W.W. 1969. Breeding the Green-billed toucan Ramphastos dicolorus at the Walsrode Bird Park. Int. Zoo Yearb. 9:134-135.

CASTRO, M.S., RECCO-PIMENTEL, S.M. \& ROCHA, G.T. 2003. Sexual dimorphism in Ramphastos toco and Ramphastos dicolorus (Piciformes, Aves). Ver. Biol. Trop. 51(1):241-246.

CEPAGRI - Centro de Pesquisas Meteorológicas e Climáticas Aplicadas à Agricultura. 2017. http://www.cpa.unicamp.br (último acesso em 03/05/2017).

COCKLE, K.L., BODRATI, A., LAMMERTINK, M. \& MARTIN, K. 2015. Cavity characteristics, but not habitat, influence nest survival of cavitynesting birds along a gradient of human impact in the subtropical Atlantic Forest. Biol. Conserv. 184:193-200.

COCKLE, K.L., BODRATI, A., LAMMERTINK, M., BONAPARTE, E.B., FERREYRA, C. \& DI SALLO, F.G. 2016. Predators of bird nests in the Atlantic Forest of Argentina and Paraguay. Wilson J. Ornithol. 128(1):120131.

FERNANDES, A.J., REIS, L.A.M. \& CARVALHO, A. 2002. Caracterização do Meio Físico. In Parque Estadual das Fontes do Ipiranga (PEFI): unidade de conservação que resiste à urbanização de São Paulo (D.C. Bicudo, M.C. Forti \& C.E.M. Bicudo, eds). Secretaria do Meio ambiente do Estado de São Paulo, São Paulo, cap. 3, p.49-62.

FILADELFO, T. 2008. Aspectos reprodutivos de Ramphastos toco (Aves: Ramphastidae) na sub-região de Miranda, Pantanal Sul Matogrossense, Brasil. Monografia de graduação, Universidade Federal da Bahia, Salvador.

FRANCISCO, M.R. 2006.Breeding Biology of the Double-collared Seedeater (Sporophila caerulescens). Wilson J Ornithol 118(1):85-90.

FONSECA, F.Y. \& ANTUNES, A.Z. 2007. Frugivoria e predação de sementes por aves no Parque Estadual Alberto Löfgren, São Paulo, SP. Rev. Inst. Flor. 19(2):81-91.

GALETTI, M., LAPS, R. \& PIZO, M.A. 2000.Frugivory by toucans (Ramphastidae) at two altitudes in the Atlantic Forest of Brazil. Biotropica 32(4b):842-850.

GUIX, J.C., RUIZ, X. \& LOVER, L. 2001.Resourse partitioning and interspecific competition among coexisting species of guans and toucans in SE Brazil Neth. J. Zool. 51(3):285-297.

HANSELL, M. 2000. Bird nests and construction behavior. Cambridge University Press, New York.

JESUS, S., BUZZATO, A.C. \& MONTEIRO-FILHO, E.L.A. 2012. Nidificação de Ramphastos dicolorus (Linnaeus, 1766) (Aves- Ramphastidae) na Região Metropolitana de Curitiba, Estado do Paraná. Ornithologia 5(1):19-25.

KNOLL, F.R.N., BEGO, L.R. \& IMPERATRIZ-FONSECA, V.L. 1993. As abelhas em áreas urbanas - Um estudo no Campus da Universidade de São Paulo. In Flores e abelhas em São Paulo (J. R. Pirani \& M. CortopassiLaurino, coord.). Edusp/Fapesp, São Paulo, p.31-42.

LANGE, R.B. 1967. Contribuição ao conhecimento da bionomia de aves: Ramphastos dicolorus L. (Ramphastidae), sua nidificação e aves. Araucariana 1:1-3.

LILL, A. 1968.Nidification in the Channel-billed Toucan (Ramphastos vitellinus) in Trinidad, West Indies. Condor 72:235-236

LÓPEZ-LANÚS, B. 2000.Collared Forest-Falcon Micrastur semitorquatus courtship and mating, with take-over of a macaw nest. Cotinga 14:9-11.

MENEZES, J.C.T. \& MARINI, M.A. 2017. Predators of bird nests in the Neotropics: a review. J. Field Ornithol. 88(2):99-114.

MOREAU, R.E.1942. The nesting of African birds in association with other living things. Ibis 84(2):240-263.

MYERS, J.G. 1935. Nesting associations of birds with social insects. Ecol. Entomol. 83:11-23.

OLIVEIRA-FILHO A.T. \& FONTES, M.A.L. 2000. Patterns of floristic differentiation among Atlantic Forests in Southeastern Brazil and the influence of climate. Biotropica 32(4b):793-810.

PEEL, M.C., FINLAYSON, B.L. \& MC MAHON, T.A. 2007. Updated world map of the Köppen-Geiger climate classification. Hydrol. Earth Syst. Sc. 11:1633-1644. 
Perrella, D.F. et al.

PIZO, M.A., DONATTI, C.I., GUEDES, N.M.R. \& GALETTI, M. 2008. Conservation puzzle: Endangered hyacinth macaw depends on its nest predator for reproduction, Biol. Conserv. 141:792-796.

RAGUSA-NETTO, J. 2008. Toco Toucan feeding ecology and local abundance in a habitat mosaic in the brazilian cerrado. Ornitol. Neotrop. 19: 345-359.

RANGEL-SALAZAR, J.L. \& ENRIQUEZ-ROCHA, P.L. 1993. Nest record and dietary items for the Black Hawk-eagle (Spizaetus tyrannus) from the Yucatan Peninsula. J. Raptor Res. 27(2):121-122.

REMSEN, J.V., HYDE JR., M.A. \& CHAPMAN, A. 1993. The diets of neotropical trogons, momots, barbets and toucans. Condor 95: 178-192.

REMSEN, J.V., ARETA JR, I.J., CADENA, C.D., CLARAMUNT, S., JARAMILLO, A., PACHECO, J.F., PÉREZ-EMÁN, J., ROBBINS, M.B., STILES, F.G., STOTZ, D.F. \& ZIMMER, K.J. 2017. A classification of the bird species of South America. http://www.museum.lsu.edu/ Remsen/ SACCBaseline.htm (último acesso em 24/03/2017).

RILEY, C.M. 1986.Observations on the breeding biology of Emerald Toucanets in Costa Rica. The Wilson Bull. 98(4):585-588.

SANTOS, A.A. \& RAGUSA-NETTO, J. 2013. Toco-toucan (Ramphastos toco) feeding habits at an urban area in Central Brazil. Ornitol. Neotrop. 24:1-13.

SHORT, L.L. \& HORNE, J.F.M. 2001. Toucans, Barbets and Honeyguides: Ramphastidae, Capitonidae and Indicatoridae. Oxford University Press, Oxford.

SHORT, L.L. \& HORNE, J.F.N. 2002. Family Ramphastidae. In Handbook of the birds of the world (J. Hoyo, A. Elliott, \& J. Sargatal, eds.). Lynx Edicions, Barcelona, v.07, p.220-272.

SICK, H. 1997. Ornitologia brasileira. Nova Fronteira, Rio de Janeiro.

SKUTCH, A.F. 1944. Life history of the blue-throated toucanet. Wilson Bull. 56(3):133-151.
SKUTCH, A.F. 1945. Incubation and nesting periods of Central American birds. Auk 62(1):8-37.

SKUTCH, A.F. 1958. Roosting and nesting of araçari toucans. Condor 60(4):201-219.

SKUTCH, A.F. 1971. Life history of the Keel-billed Toucan. Auk 88:381-424.

TATTERSALL, G.J., ANDRADE, D.V. \& ABE, A.S. 2009. Heat Exchange from the toucan bill reveals a controllable vascular thermal radiator. Science 325:468-470.

VAN TYNE, J. 1929. The life history of the Toucan Ramphastos brevicarinatus. Miscellaneous Publications, n.19, Michigan.

WESOŁOWSKI, T. 2002. Anti-predator adaptations in nesting marsh tits Parus palustris: the role of nest-site security. Ibis 144:593-601.

WESOŁOWSKI, T. \& ROWIŃSKI, P. 2004. Breeding behaviour of Nuthatch Sitta europaea in relation to natural hole attributes in a primeval forest. Bird Study 51:143-155.

WESOŁOWSKI, T. \& ROWIŃSKI, P. 2012. The breeding performance of Blue Tits Cyanistes caeruleus in relation to the attributes of natural holes in a primeval forest. Bird Study 59:437-448.

WINKLER, D.W. 2004. Nests, eggs, and young: breeding biology of birds. In Cornell lab of Ornithology Handbook of Bird Biology (S. Podulka, R.W. Rohrbaugh Junior \& R. Bonney, eds.). Princeton, University Press Princeton, p.8.1-8.152.

ZHU, X., SRIVASTAVA, D.S., SMITH, J.M.N. \& MARTIN, K. 2012. Habitat selection and reproductive success of Lewis's Woodpecker (Melanerpes lewis) at its northern limit. Plos One 7:e44346.

Received: $29 / 04 / 2018$

Revised: 23/11/2018

Accepted: $12 / 12 / 2018$

Published Online: 24/01/2019 